\title{
Managing Soils for Recovering from the COVID-19 Pandemic
}

Rattan Lal $^{1, *}$, Eric C. Brevik ${ }^{2} \mathbb{D}$, Lorna Dawson ${ }^{3}$, Damien Field ${ }^{4}\left(\mathbb{D}\right.$, Bruno Glaser ${ }^{5}$ (D), Alfred E. Hartemink ${ }^{6}{ }^{\mathbb{D}}$, Ryusuke Hatano ${ }^{7}{ }^{\mathbb{D}}$, Bruce Lascelles ${ }^{8}$, Curtis Monger ${ }^{9}$, Thomas Scholten ${ }^{10}$, Bal Ram Singh ${ }^{11}$, Heide Spiegel ${ }^{12}\left(\mathbb{D}\right.$, Fabio Terribile ${ }^{13}$, Angelo Basile ${ }^{14}$ (D), Yakun Zhang ${ }^{6}$, Rainer Horn ${ }^{15}\left(\mathbb{D}\right.$, Takashi Kosaki ${ }^{16}$ and Laura Bertha Reyes Sánchez ${ }^{17}$

1 Carbon Management and Sequestration Center, SENR, The Ohio State University, 210 Kottman Hall, 2021 Coffey Road, Columbus, OH 43210, USA

2 Departments of Natural Sciences and Agriculture and Technical Studies, Dickinson State University, Dickinson, ND 58601, USA; Eric.Brevik@dickinsonstate.edu

3 Forensic Soil Science, Environmental and Biochemical Sciences Department, The James Hutton Institute, Aberdeen AB15 8QH, UK; lorna.dawson@hutton.ac.uk

4 Sydney Institute of Agriculture \& School of Life and Environmental Science, Faculty of Science, The University of Sydney, Camperdown, New South Wales 2006, Australia; damien.field@sydney.edu.au

5 Soil Biogeochemistry, Institute of Agronomy and Nutritional Sciences, Martin Luther University Halle-Wittenberg, Von-Seckendorff-Platz 3, D-06120 Halle, Germany; bruno.glaser@landw.uni-halle.de

6 Department of Soil Science, FD Hole Soils Lab, University of Wisconsin-Madison, Madison, WI 53706, USA; hartemink@wisc.edu (A.E.H.); zhang878@wisc.edu (Y.Z.)

7 Research Faculty of Agriculture, Hokkaido University, Kita 9, Nishi 9, Kita-ku, Sapporo 060-8589, Japan; hatano@chem.agr.hokudai.ac.jp

8 Environmental Planning, Arcadis Consulting Ltd, Bristol BS2 0FR, UK; Bruce.Lascelles@arcadis.com

9 Department of Plant and Environmental Sciences, New Mexico State University, P.O. Box 1018, Farmington, NM 87499, USA; cmonger@nmsu.edu

10 Department of Geosciences, University of Tübingen, 72070 Tübingen, Germany; thomas.scholten@uni-tuebingen.de

11 Faculty of Environmental Sciences and Natural Resource Management, Norwegian University of Life Sciences, P. O. Box 5003, 1433 Ås, Norway; balram.singh@nmbu.no

12 Department for Soil Health and Plant Nutrition, Austrian Agency for Health and Food Safety, Spargelfeldstrasse 191, A-1220 Vienna, Austria; adelheid.spiegel@ages.at

13 Interdepartmental Research Centre on the "Earth Critical Zone" for Supporting the Landscape and Agroenvironment Management (CRISP), University of Naples Federico II, 8055 Portici (NA), Italy; terribil@unina.it

14 Institute for Agricultural and Forestry Systems in the Mediterranean (ISAFOM), National Research Council of Italy (CNR), Piazzale Enrico Fermi 1, 80055 Portici (NA), Italy; angelo.basile@cnr.it

15 Institute for Plant Nutrition and Soil Science, Christian-Albrechts University Kiel, Hermann Rodewaldstr. 2, 24118 Kiel, Germany; rhorn@soils.uni-kiel.de

16 Department of Global Liberal Arts, Aichi University, Nagoya 453-8777, Japan; kosakit8@vega.aichi-u.ac.jp

17 Agricultural Engineering Department, National Autonomous University of Mexico, Campus Cuautitlán Izcalli, México 54750, Mexico; lbrs@unam.mx

* Correspondence: lal.1@osu.edu

Received: 26 June 2020; Accepted: 20 July 2020; Published: 28 July 2020

\begin{abstract}
The COVID-19 pandemic has disrupted the global food supply chain and exacerbated the problem of food and nutritional insecurity. Here we outline soil strategies to strengthen local food production systems, enhance their resilience, and create a circular economy focused on soil restoration through carbon sequestration, on-farm cycling of nutrients, minimizing environmental pollution, and contamination of food. Smart web-based geospatial decision support systems (S-DSSs) for land use planning and management is a useful tool for sustainable development. Forensic soil science can also contribute to cold case investigations, both in providing intelligence and evidence in
\end{abstract}


court and in ascertaining the provenance and safety of food products. Soil can be used for the safe disposal of medical waste, but increased understanding is needed on the transfer of virus through pedosphere processes. Strengthening communication between soil scientists and policy makers and improving distance learning techniques are critical for the post-COVID restoration.

Keywords: COVID-19 pandemic; circular economy; food security; soil management; urban agriculture; soil carbon sequestration; forensic soil science; geographical information systems; soil disposal of medical waste; connecting soil science with policy makers

\section{Introduction}

The COVID-19 pandemic has impacted global food and nutritional security by disrupting the food supply chain from the farm gate to the household. The lockdown has led to shortages and increased wheat price by $8 \%$ and rice by $25 \%$, compared with those in March 2019 [1]. Before COVID-19, 820 million people were undernourished and 2 billion malnourished [2]. Many millions more are living perilously close to the poverty line, lacking the economic and physical means to procure food in light of enforced social isolation, movement restrictions, supply interruptions, lost income, and food price spikes. The crisis is also affecting the quality of human diets. People are shifting towards greater consumption of heavily processed food, with fresh fruits and vegetables less available and/or more expensive in conventional supply chains. This could create vicious circles: diabetes and other diet-related non-communicable diseases are risk factors for COVID-19 mortality [2]. The pandemic has affected both staple commodities and high-value commodities [3]. The logistics to distribute staple commodities is affected as transportation across cities, provinces, regions, and countries is hampered. The high-value commodities are affected by labor shortages. Remote and food insecure areas are particularly susceptible to transportation challenges, where the majority of food in grocery stores is flown into the communities [4].

In view of such global developments, soil plays a central role as a production factor in individual agricultural enterprises, and also as a basic condition for the resilience and productivity of agriculture in times of crisis. Managing soils for both recovery from the COVID-19 pandemic and long-term sustainability is of great importance not only to sustain yields but also to keep the soil healthy for many other functions and for future generations.

Recovery from the COVID-19 pandemic can be accelerated by restoring soil quality and functionality through application of modern innovations that strengthen the resilience of the local food production system while improving environmental quality. The importance of understanding the interconnectivity between the COVID-19 pandemic and human wellbeing on the one side and that of soil health and functionality on the other side can never be over emphasized (Figure 1). Therefore, in this article, we offer strategies to alleviate human suffering through the innovative management of soil resources. The specific objective of this article is to deliberate the importance of sustainable soil management and restoration to recover from the adverse impacts of the COVID-19 pandemic through improved sustainable food production and distribution to minimize vulnerability to hunger and malnutrition. 


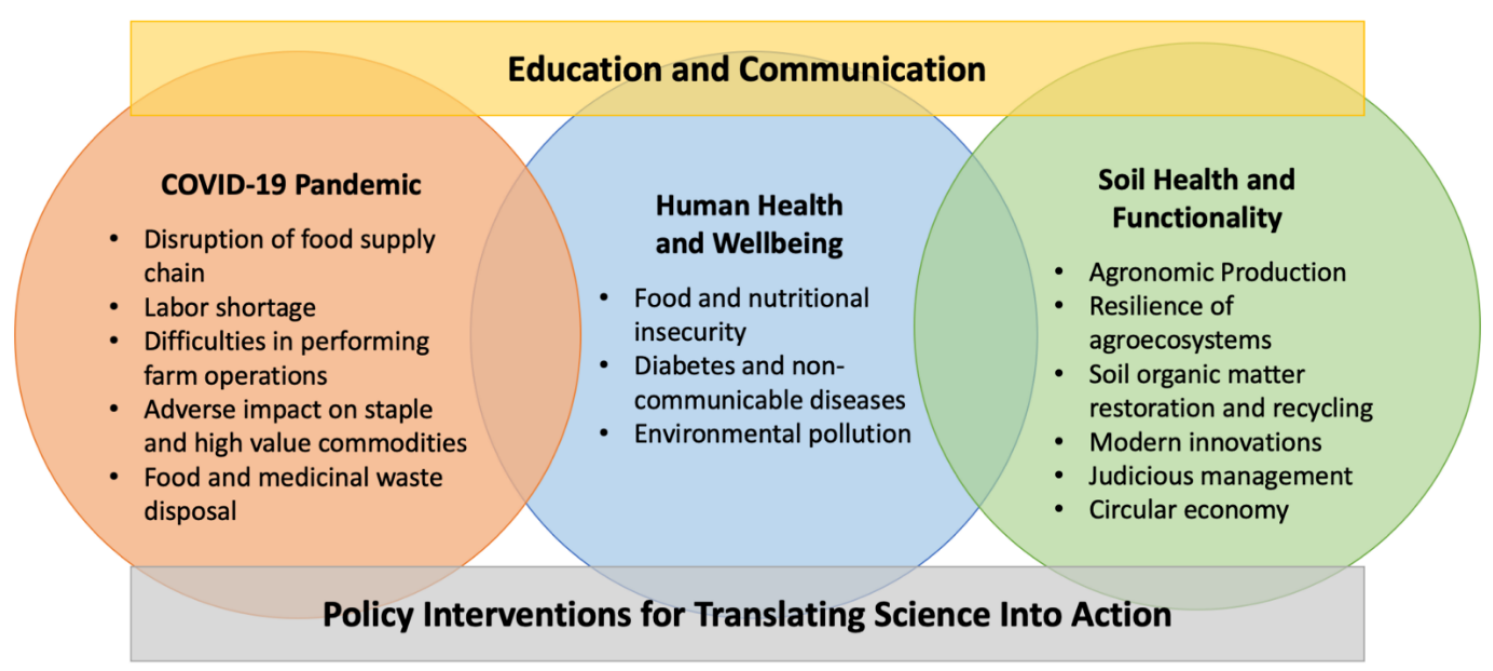

Figure 1. Sustainable management of soil resources for enhancing recovery from the COVID-19 pandemic by strengthening the food supply chain and improving environmental quality.

\section{Soil Health}

The most immediate impacts of the COVID-19 pandemic on soil and vice versa are through human activities (Figure 2) resulting from a decline in human consumption giving rise to surplus food that is being disposed of and added to soil. Reduced consumption of meat led to food waste and the use of U.S. Department of Agriculture (USDA) soil maps to locate sites suitable for mass burials of swine and poultry in the US during March to May 2020 [5]. This has long-term consequences to land use, groundwater quality, biodiversity, human health, and land value. A potato glut has occurred due to a decline in the consumption of French fries, resulting from the cancellation of sporting and cultural events as well as the closure of restaurants. This huge potato surplus impacts soil when farmers plow under crops and plan to discard surplus potatoes currently in storage by working them into soil on a scale never seen before [6]. A similar supply-chain-soil situation is faced by dairy farmers (discarding millions of gallons of milk per day), and also impacting upon beef producers. This is being followed by a reduction in acreage being planted to adjust to decreased demand.

Sustainable management of soil towards nutrition-enhanced food production through restoration of soil health is critical to reducing the risks of food and nutritional insecurity. A low content of soil organic matter (SOM) in the root zone can reduce protein content in wheat [7], and decrease productivity of smallholder agriculture [8]. Nutritional quality of organically grown food may be better than that of fertilizer-based management $[9,10]$. The SOM content is also adversely affected by accelerated soil erosion [11], salinization, and other degradation processes that create a negative soil/ecosystem carbon budget [12]. Soil health is closely linked to SOM content and its management [13], and soil degradation is an important factor in inadequate human nutrition [14].

Soil resilience is a key element of overall soil quality or soil health. It is central to sustainable land management and, therefore, to food and other natural products' supply and security, as well as the ability of a soil to recover from degradation [15-17]. Soil microbial communities are critical to soil resilience and are influenced by soil physiochemical structures and processes [18]. From a functional perspective, resilient soil addresses basic soil functions such as biomass production, including agriculture and forestry, and storing, filtering, and transforming nutrients, substances, and water [19]. These functions and services enable soils to support the basic supply of food and natural products required by human population even under high external pressure and has moved the importance of soil functions higher on the agenda in soil science research [20] as well as in a policy setting.

In addition to the primacy of human health care, the maintenance of all critical infrastructures and, in particular, the supply of the population with food and natural products from agriculture, forestry, and fisheries has the highest priority, and it has increasingly been challenged under the COVID-19 
pandemic [21]. Besides nutrition, the social dimension, such as disruptions in food prices, is also important [22]. A decline in soil health and resiliencies is also a constraint to advancing Sustainable Development Goals of the United Nations [23].

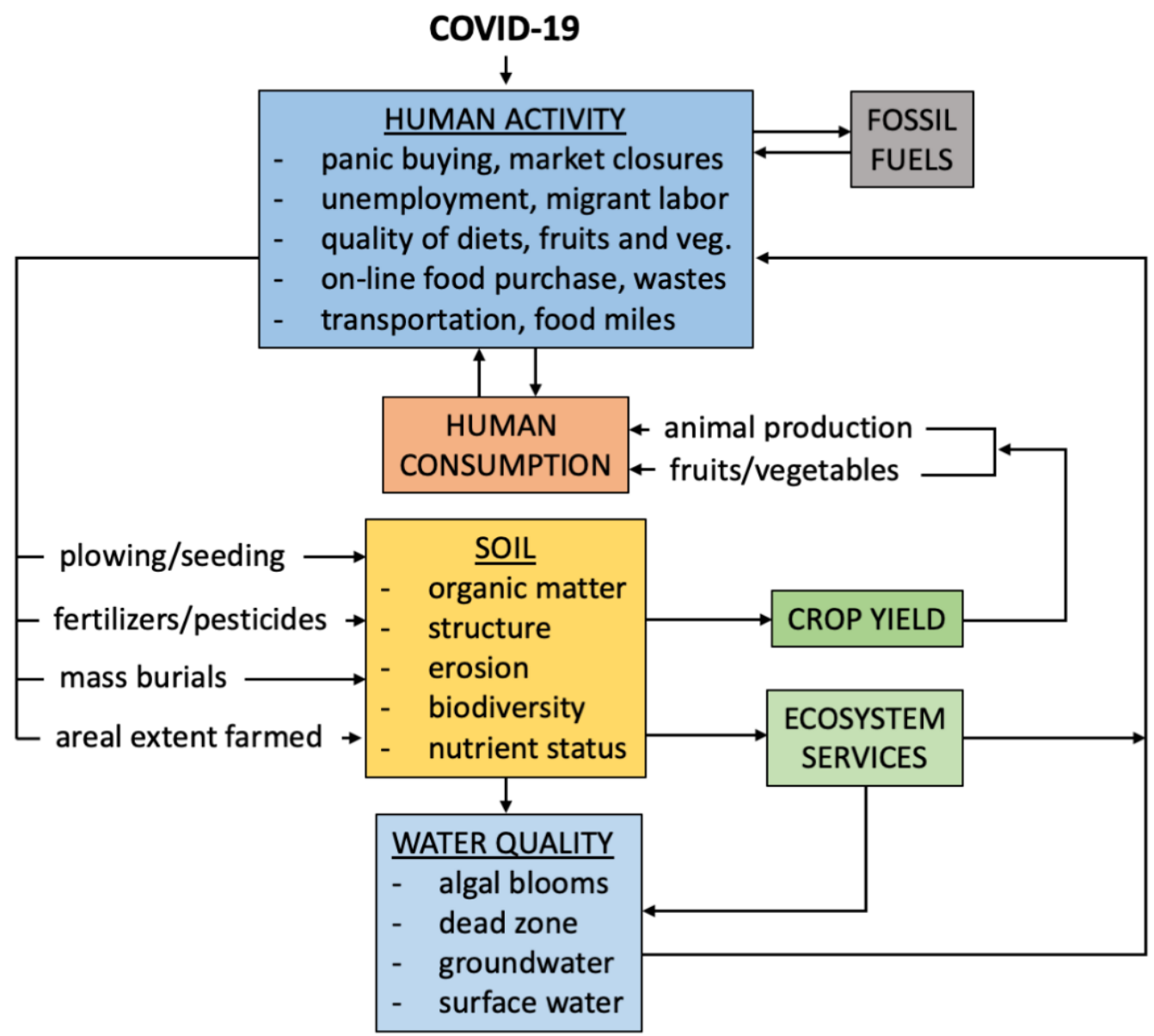

Figure 2. Links and feedbacks illustrating how soil is being impacted by COVID-19.

In recent years, the increase of extreme weather events, especially pronounced dry spells, has already had a massive impact on aspects of both agriculture and forestry. Only in areas with sufficient water storage in the soil can yield losses that remain within acceptable limits [24]. However, the geographical distribution of soils and their quality and health varies spatially on all scales, from climatic zones to individual fields [25]. Therefore, not only the protection of soil and the preservation of its functions, but also the use of soils under the aspect of resilience to crises such as the COVID-19 pandemic must be approached site-specifically. Diversification of agricultural and forestry production and products [26] represents one essential step to combat global crises such as COVID-19. For example, the combination of animal husbandry, fodder and food cultivation and production in integrated farming systems [27] could provide a high degree of flexibility on a regional and national scale and enable rapid adaptation to changing conditions and to respond to site-specific soil conditions.

Another important future need is to limit or even end soil loss. In many countries, the soil is stressed from many sides, increasingly built over, sealed, polluted, and eroded. Aiming at land degradation neutrality is a high priority.

\section{Soil Health and Human Health}

The idea that soils influence human health extends back to antiquity [28-30]. A major landmark in bacteriology and medical science was Robert Koch's 1870 discovery that the cause of anthrax was Bacillus anthracis, which lives in soil, and in 1880 Luis Pasteur showed that earthworms could transfer 
anthrax spores to the soil surface where exposure could occur [31]. The 20th century saw an increase in interest concerning links between soils and human health spanning multiple countries and continents. Links between soil fertility and the quality of food products continued to receive attention, knowledge concerning soil microorganisms increased, and antibiotics were isolated from soil microorganism [32]. Viruses that cause a range of diseases including hepatitis, gastroenteritis, respiratory diseases, polio, meningitis, and smallpox were all found in soil, usually in association with the disposal of human and/or animal waste products $[33,34]$. By the end of the $20^{\text {th }}$ century, connections between soil and human health were well established, although there was still a need for well-designed scientific studies to expand knowledge [35].

Presently, there is a strong need to address some of the short- and long-term implications from the current COVID-19 crisis and the role that soil science can play in mitigating against its immediate and long-term effects. Hurst et al. [36] found that virus survival was significantly affected by the soil temperature, moisture content, presence of aerobic microorganisms, degree of virus adsorption to the soil, soil levels of resin-extractable phosphorus, exchangeable aluminum, and soil $\mathrm{pH}$. According to Abrahams [37], viruses in soils and the dust of desert regions may have contributed to increases in respiratory diseases such as asthma and that the smallpox virus will not remain viable for long following earth burial whereas in cool, dry conditions the virus may survive. While a lot is known about viruses in the soil, the potential presence and behavior of COVID-19 in the soil is not known. In a study conducted by Walter et al. [38], soil clay content, particularly the presence of montmorillonite, enhanced prion transmissibility. The potential survival and transmissivity of the COVID-19 virus in soils and other environmental media [39] and their relationships with soil properties and environmental conditions should be evaluated. One of the critical needs of the post COVID-19 world is building a broader awareness of the importance of soils to human health and how to manage soil to enhance the health of soil, plants, animals, people, and the environment.

\section{Food Security}

The COVID-19 pandemic has made it more difficult to secure foodstuffs because of movement restrictions and border closures. This has driven new initiatives to produce regional food. In recent years, the trend has been towards a decrease in available agricultural land and an increase in the human population, leading to conflicting interests for land use [40,41]. Moreover, climate change impacts soils and biomass production through extreme weather such as severe droughts, tornados and heavy precipitation events. All these scenarios, beyond COVID-19, strongly suggest the need to further develop existing initiatives to increase the efficiency of resource use (i.e., fertilizer, energy, and water) through the adoption of innovations such as sensor and satellite technologies.

One aspect that needs to be considered during the COVID-19 crisis is the impact of mineral fertilization omissions on soils and the production function. It is important to more closely examine $\mathrm{N}$ and $\mathrm{P}$, which are essential macronutrients; $\mathrm{N}$ often limits crop production the most [42], but $\mathrm{P}$ fertilization has also contributed to increased crop yields in the last century [43]. In general, sustainable nutrient management consists of fertilization that replaces the amount of nutrients removed by the crop harvest [44].

Agronomists and soil scientists have shown that "nutrient mining" systems are often connected with subsistence agriculture in tropical areas and sometimes also with extensive farming in Europe [44]. During the COVID-19 pandemic, nutrient mining may well also become a scenario in industrial countries because fertilizers are often produced outside the country and border restrictions may prevent or limit fertilizer imports.

Agriculture should always, and even more so during the times of pandemic crises, sustainably use all available organic fertilizers such as farm manures $[45,46]$. Applying quality-controlled organic residues from industry on agricultural land may contribute to an extensive circular economy. Reducing mineral P fertilizers may also help decrease the input of harmful trace elements such as cadmium or uranium [47]; the application of secondary raw material fertilizers should be monitored by quality 
control measures $[48,49]$. In the past, intensive farming with excessive $\mathrm{N}$ and $\mathrm{P}$ fertilization have caused nutrient losses to surface and subsurface water, generating environmental harm in the form of nitrate leaching and eutrophication [50,51]. Moreover, $\mathrm{N}$ losses to the atmosphere occur through ammonia $\left(\mathrm{NH}_{3}\right)$ volatilization and emissions of the primary and secondary greenhouse gases $\mathrm{N}_{2} \mathrm{O}$ and $\mathrm{NO}$ [52], and $\mathrm{CH}_{4}$ emission due to mechanical stresses applied by non-site adjusted agricultural machines, converting soils from sink to source [53].

Heavy metal accumulation in agricultural soils may also lead to elevated uptake of metals in edible parts of food crops, affecting food quality and safety and creating potential human health risks [54]. Metals can cause several acute as well as chronic poisoning in humans (Table 1). There is growing support for the reintegration of mixed livestock and cropping farming systems, which are known to improve on-farm cycling of nutrients and reduce the need for off-farm waste management [27].

The COVID-19 restrictions, with lower fertilizer availability and application, may lead to improved farm management with consequential reduced emissions of greenhouse gases (GHGs), including $\mathrm{N}_{2} \mathrm{O}$, $\mathrm{NH}_{3}$ emissions, and $\mathrm{NO}_{3}$ leaching to waters, along with overall improved nitrogen use efficiency and less heavy metal accumulation in soils. This would mean reduced environmental impacts, increased food quality and a food system that rebounds within safe planetary boundaries [55].

Table 1. Clinical aspects of chronic toxicities (modified and adopted from Mahurpawar [56]).

\begin{tabular}{|c|c|c|}
\hline $\begin{array}{c}\text { Metal Contributing } \\
\text { to Toxicity }\end{array}$ & Target Organs & Clinical Effects \\
\hline Arsenic & Pulmonary Nervous System, Skin & $\begin{array}{l}\text { Perforation of Nasal Septum, Respiratory } \\
\text { Cancer, Peripheral Neuropathy: } \\
\text { Dermatomes, Skin, Cancer }\end{array}$ \\
\hline Cadmium & Kidneys, Skeletal Pulmonary System & $\begin{array}{c}\text { Proteinuria, Glucosuria, Osteomalacia, } \\
\text { Aminoaciduria, Emphysema }\end{array}$ \\
\hline Lead & $\begin{array}{l}\text { Nervous System, Hematopoietic } \\
\text { System, Kidneys }\end{array}$ & $\begin{array}{l}\text { Encephalopathy, Peripheral Neuropathy, } \\
\text { Central Nervous Disorders, Anemia }\end{array}$ \\
\hline Mercury & Nervous System, Kidneys & Proteinuria \\
\hline
\end{tabular}

\section{Circular Economy and Urban Agriculture}

Combined with the ongoing focus on an increasing global population and the local impacts of COVID-19, the circular economy may maximize the utilization of resources by minimizing their depreciation [57] and reducing leakage to the environment through resource recovery, reuse, or repurposing $[58,59]$.

Of all human activities, the production of food has by far the largest areal impact on soil's ability to provide needed services and, if compromised, can have severe consequences on society and the environment [57]. Two immediate effects of the COVID-19 pandemic have resulted in future concerns about supply shocks due to international trade disruptions: (1) the potential increase in waste from the public's panic buying reaction, and (2) realization of the limited resources held by nation states, e.g., the supply of inorganic fertilizers and fuels to support future food production. This has raised questions about how the resilience and productivity of local food systems can be improved, the reliance on external supplies can be reduced, and the potential for increased food wastage and its management realized.

Urban farming or gardening is often thought of as a way to contribute to local food systems. In highly centralized urbanized nations, the ability to preserve and plan spaces for soil to provide green areas, parks, and the ability for local communities to grow food is increasing and becoming part of the public policy and planning. The preservation of these soil spaces also impacts the ability to store water and reduces the urban heat island effect [60]. Planning for urban gardens can result in a positive effect on local community well-being through promoting healthy behavior and a sense of security [61].

In urban environments, circular economies of food and other biological wastes are viewed as a resource for nutrient recovery, which can be used locally or in the agricultural sector more 
broadly. Residues should be diverted into composting programs to close the loop, avoiding the loss of, and reducing the need to import, nutrients for food production. Such practices will also simultaneously minimize environmental impacts such as eutrophication of waterways and a loss of leachates from landfills but will require the necessary infrastructure and policy frameworks to be created. Building these will lessen the need for solely imported nutrients (e.g., chemical fertilizers) and expulsion of waste from urban environments, meeting the circular economy's aspirations of resource recovery and reducing leakage.

A paradigm shift from industrial agriculture to more diversified agroecological systems is more urgent than ever. Agroecology's unique capacity to reconcile the economic, environmental, and social dimensions of sustainability has been recognized by the Food and Agriculture Organization of the U.N. (FAO), landmark reports from the Intergovernmental Panel on Climate Change (IPCC), Intergovernmental Science-Policy Platform on Biodiversity and Ecosystem Services (IPBES), and the World Bank and FAO-led global agriculture assessment. Agroecology builds resilience by combining different plants and animals, and uses biobased circular economy strategies such as the "Terra Preta" concept, or permaculture, to regenerate soils, fertilize crops, and fight pests [62]. It is thus less dependent on imported inputs such as fertilizers and pesticides, thereby reducing vulnerability to trade disruptions and price shocks. Territorial markets and short supply chains are often a key component of agroecological systems, and can enhance access to fresh food, ensure a greater value goes back to the grower, and reduces vulnerability to disruptions on international markets.

Soil, generated through material cycling [63], contains humic substances and clay minerals, which retain nutrients and interfere with acids because of electrically charged surfaces (Figure 3). Regular input of compost can create a positive SOM budget in cropland [64]. Prospects for a long-term global economic downturn due to the COVID-19 pandemic are likely to reduce prices for a fertilizer. However, the indiscriminate use of chemical fertilizers can decrease soil $\mathrm{pH}$ over time. However, $\mathrm{N}_{2} \mathrm{O}$ emissions are significantly lower with compost than with chemical fertilizers [65], and use of compost pellets can potentially further reduce $\mathrm{N}_{2} \mathrm{O}$ emissions [66]. Thus, technological development for promoting organic agriculture based on material cycling must be an important consideration.

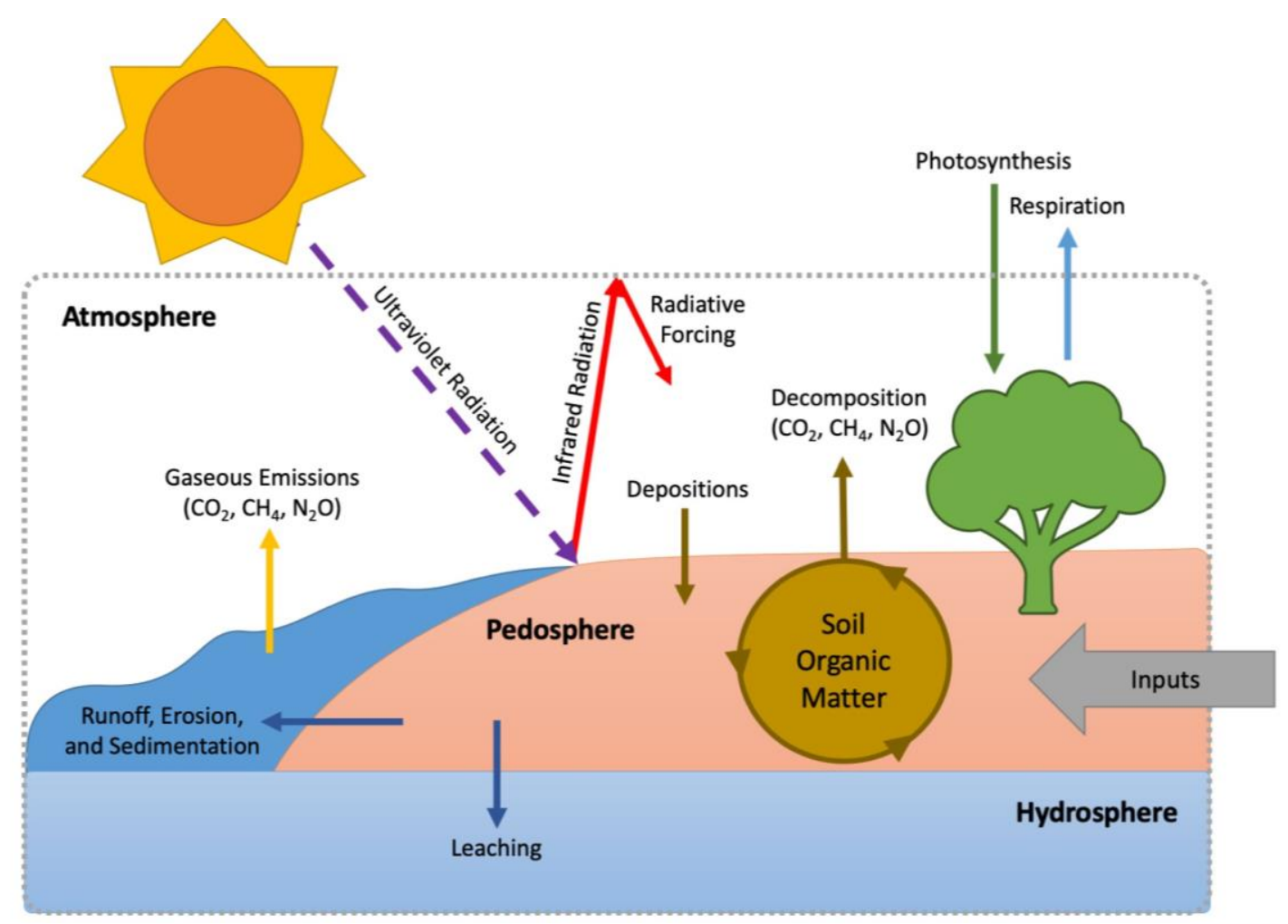

Figure 3. Cycles of energy, water, and materials cross through soil. 
The experience of COVID-19 has highlighted that the movement of perishable food is problematic, but it has also refocused concerns about the ability to supply and store resources that support food production. There has been a long running concern about the looming global shortage of phosphate [67] and, in the event of trading limitations in the future, the ability for nations to produce enough inorganic nitrogen. This tyranny of distance makes the use of waste as a resource to offset some of the need for inorganic sources of fertilizer a challenge that needs immediate attention towards the export of surplus organic waste from urban environments to broadacre agricultural lands.

\section{Soil Management Beyond the COVID-19 Pandemic}

Soil science has addressed grand environmental challenges such as climate change, global food production, biodiversity loss, water quality and quantity, and biodiversity [68-70]. The global COVID-19 crisis forces the soil science discipline to address short-term issues such as changes in the food supply chain and its possible relation to soil management as well as human health implications. Some environmental quality indicators, air quality in particular (e.g., $\mathrm{PM}_{2.5}$ and $\mathrm{NO}_{2}$ emission), have shown an improvement due to the reduction of economic activities during the COVID-19 pandemic [71,72]. Some studies have suggested that air quality (e.g., $\mathrm{NO}_{2}$ emission) and meteorological conditions (e.g., wind speed and direction) affected the transmission of and death rates attributed to COVID-19 [73], and soil management can influence air quality.

The impacts of organic waste in developing countries on the quality of air and water has been highlighted by the reprieve waterways, which have been experienced during the COVID-19 closedown [74]. In regions with small-holder farming systems the promotion of diverse farming systems have improved and supported soil fertility and reduced the impact of pests and diseases on production systems [75]. A significant long-term impact of developing these integrated cropping systems will enable sufficient intensification to avoid encroachment into natural systems that increases risks to pandemics such as by COVID-19 [76], but also supports the soil's ability in natural systems to provide a range of ecosystem services. It will also reduce the dependence on mineral resources. This needs to be complemented by financial instruments that are attractive to the private sector. In the USA and EU direct payments are made to soil managers to support ongoing ecosystem services and allocation of productive land to provide natural capital. The recognition of "green" credentials or good land management associated with producing a product will also contribute to sustaining the soil resource.

Humanity is facing the complex task of attempting to challenge the combined global crises of COVID-19, climate change, and the environmental crisis. These crises are exacerbated by the current fragmentation over landscape issues: (i) multiscale fragmentation of land policies, (ii) separate management of land for environmental and agricultural issues, and (iii) incomplete and fragmented geospatial knowledge about land and soil processes and properties. Smart web-based geospatial decision support systems (S-DSSs) for land planning and management-having the soil as a pulsing heart-promise to overcome some of the above problems (e.g., www.landsupport.eu) giving new hope to a more sustainable development. These systems, developed from the open-source geospatial cyber-infrastructure platform [77,78], combines land and soil databases (including digital-soil-mapping, Earth-observation), a suitable modeling engine, high performance computing (HPC), and datacube technologies. The magnitude of the effect of COVID due to a proper graphical user interface can produce a freely available web-based system addressing the sustainable use of land and soils by combining large spatial extent (e.g., country/continent scale) and high spatial detail (e.g., $20 \mathrm{~m}$ Sentinel resolution).

Several case studies of such soil-based S-DSSs are currently available at the local scale for planning and management of viticulture [79], olive growth [80], and forest resources [81], and soil sealing and urban planning, for specific areas [82] or even an entire country [83] for a multi-stakeholder community including spatial planners. 


\section{Soil Science Beyond the COVID-19 Pandemic}

The effect of COVID-19 on food production $[4,84]$, economics $[85,86]$, society $[87,88]$, and public health issues such as weight gain $[89,90]$ must be assessed. Currently, the virus is spreading in other parts of the world, particularly in rural regions where subsistence farming and smallholders are dominant. Those systems are highly sensitive to disturbances and food inequality and shortages may therefore be expected or even exacerbated in the economically less developed regions of the world [91].

While a lot is known about viruses in the soil, the potential presence and behavior of COVID-19 in the soil is not known. Soil properties that affect the transmission and survival of viruses in the natural environment need to be further understood. Soil materials (and pollen and plant fragments) have been used as forensic trace evidence for many years, even from Roman times, and are often highly distinctive from one region to another [92]. Such traces are extremely useful in a forensic and in a virologic context, because of their environmental specificity; their high levels of transferability; their ability to persist on items such as clothing, footwear, tools, and vehicles; and their high levels of preservation after long periods of time. Never has the importance of working in a global framework been brought into focus more than with the COVID-19 pandemic. There is a strong appeal for scientists modeling the COVID-19 pandemic and its consequences for health and society to rapidly and openly publish their code, along with specifying the type of data required, model parametrizations and any available documentation, so that it is accessible to all scientists around the world [93]. Significant advances have been made in soil science over the past decade, in the development of analytical approaches, miniaturization, digital spatial tools such as geographical information systems (GISs), and also in understanding the behavior, transfer, persistence, and preservation of sediments, soils, and plant material, which has widened their applicability [94]. All that research has enabled a stronger evidence base for government policies to be developed in the COVID-19 situation. Soil samples can be analyzed using a broad range of complementary methods that address their physical, chemical, and biological components with greater precision, speed, and accuracy than ever before [92,95]. For example, this now permits samples of less than 10 milligrams to be accurately characterized and permits forensic soil science to also contribute to cold case investigations, both in providing intelligence and evidence in court and in ascertaining the provenance and safety of food products for example.

The communication of soil science to the general public is of vital importance, in particular within the adversarial systems of justice, where the juries in court are the triers of fact [96]. There has never been a more important time for effective communication.

A great amount of medical waste has been produced during the COVID-19 outbreak, including used personal protective equipment, tissue papers, plastic bags, and empty bottles of sanitizers and hand soaps $[97,98]$. Effective management of the medical waste through burning or decontamination processes should be carefully conducted before any exposure to the environment occurs (e.g., soil, water, and ocean). The daily consumption of face masks and gloves by millions of people may create high risks to the community and environment [97]. Soil pollution related to the increased medical and other organic and inorganic wastes should be closely monitored.

Most of the university educational programs have moved to online-teaching to facilitate personal-distancing [87]. This will work for the general principles and practices of teaching soil science, but it will not replace laboratory or field experiences. Employers require graduates who have 'hands-on' experience in sampling, analysis, and evaluation of site conditions and case contexts. If this crisis were to continue over a prolonged period, it is important to develop teaching methods that mimic the 'hands-on' experience.

\section{Connecting Soil Science with Policy Makers and Stakeholders}

The COVID-19 pandemic necessitates translation of scientific knowledge about soil and its management into action through identification and implementation of policies that restore soil, halts its loss, promotes nutrition-sensitive agriculture, and reconciles the need to meet the demands of humanity for basic necessities with the urgency to restore the environment and mitigate global warming. It is 
thus important to support global initiatives such as "4 per 1000" launched at the COP21 in Paris during 2015. Soil scientists must also seize the moment and be actively involved in initiatives launched at COP22 in Marrakech regarding "Adapting African Agriculture" [99] and Platform for Climate Action in Agriculture (PLACA) launched at COP25 in Madrid/Chile. Sustainable management of soil and agriculture must be integral to addressing the emerging but overlapping and interconnected issues of the $21^{\text {st }}$ century such as the COVID-19 pandemic, global warming, hunger and malnutrition, water scarcity and renewability, and dwindling biodiversity. Judicious management of soil is critical to advancing the Sustainable Development Goals of the United Nations. The issue of food and nutritional security must be addressed through strengthening of local food production systems based on home gardening and urban agriculture. These topics must be high on the agenda when the postponed COP26 UN climate conference, now planned for the 1-12 November 2021 in Glasgow, is held.

The effects of the pandemic on soil quality may occur through several routes: interrupted food chain, irregular food production, disturbance to agricultural commodities, and opportunistic soil management behavior [100]. This is an opportunity to rethink the US food chain that has become highly dependent on large corporations and less on the output from family-farms. A similar trend is developing in parts of Europe. In other parts of the world there is a risk of food shortages and inequalities when COVID-19 spreads to rural areas and smallholder farmers.

Soil science must also be connected with the general public—as the food consumer and beneficiary of other ecosystem services provisioned through soil and its management. Farmers and land managers must be rewarded and incentivized through payments for ecosystem services such as carbon sequestration, water quality and renewability, soil biodiversity, etc. The COVID-19 tragedy necessitates a paradigm shift towards increasing awareness about the importance of soil in addressing existing and emerging global issues. The virus outbreak, and responses to it, have focused attention worldwide on the interaction between science, experts, society, policy making, and politics, and have highlighted the vital importance of international scientific collaboration and open, accessible, and reliable sources of information such as through organizations such as International Union of Soil Sciences (IUSS).

Author Contributions: R.L. wrote the abstract, introduction, and conclusion, and synthesized and edited the entire manuscript. E.C.B. wrote on the theme of the historical links between soils and human health and edited the manuscript. L.D. wrote on the theme of soil science in delivering global security in the context of post COVID-19 recovery and edited the manuscript. D.F. wrote on the theme of reflections post COVID-19 on soil in the circular economy and edited the manuscript. B.G. and C.M. wrote on the theme of the role of the COVID-19 pandemic health crisis on supply chains and on regional and urban agriculture, supplied Figure 1, and edited the manuscript. A.E.H. and Y.Z. wrote on the theme of the role of soil science in a global crisis like the COVID-19 pandemic and edited the manuscript. R.H. (Ryusuke Hatano) wrote on the theme of the importance of organic matter management based on material cycling through soil, supplied Figure 2, and edited the manuscript. B.L. edited the manuscript. T.S. wrote on the theme of resilient soils as a key element to secure the basic supply of our population with food and natural products and edited the manuscript. B.R.S. wrote on the theme of human health risks of heavy metals in recycled biowastes under COVID-19 food demands, supplied Table 1, and edited the manuscript. H.S. wrote on the theme of soils, food security and COVID-19 and edited the manuscript. F.T. and A.B. wrote on the theme of geospatial decision support Systems to reinforce land planning and management in the global COVID-19 crisis and edited the manuscript. R.H. (Rainer Horn), T.K., and L.B.R.S. reviewed the manuscript and provided various fact and reference checks. All authors have read and agreed to the published version of the manuscript.

Funding: This research received no external funding.

Acknowledgments: This paper is a contribution of the International Union of Soil Sciences Research Forum.

Conflicts of Interest: The authors declare no conflict of interest.

\section{References}

1. Torero, M. Without food, there can be no exit from the pandemic. Nature 2020, 580, 588-589. [CrossRef] [PubMed]

2. IPES-Food. COVID-19 and the Crisis in Food Systems: Symptoms, Causes, and Potential Solutions. 2020, pp. 1-11. Available online: http://www.ipes-food.org/_img/upload/files/COVID-19_CommuniqueEN.pdf (accessed on 21 July 2020). 
3. Cullen, M.T. COVID-19 and the Risk to Food Supply Chains: How to Respond; FAO: Rome, Italy, 2020. [CrossRef]

4. Deaton, B.J.; Deaton, B.J. Food security and Canada's agricultural system challenged by COVID-19. Can. J. Agric. Econ. Can. d'agroeconomie 2020. [CrossRef]

5. Web Soil Survey. Suitabilities and Limitations for Use; Disaster Recovery Planning; Catastrophic Mortality, Large Animal Disposal, Trench. 2020. Available online: http://websoilsurvey.nrcs.usda.gov (accessed on 21 July 2020).

6. Bernton, H. In French Fry Heaven, Spring Turns Bitter. The Seattle Times. 2020. Available online: https: //www.seattletimes.com (accessed on 21 July 2020).

7. Pol, E. Is Low Protein Wheat a Symptom of Low Soil Organic Matter? GRDC Communities. 2019. Available online: https://communities.grdc.com.au/crop-nutrition/low-protein-wheat-symptom-low-soil-organicmatter/ (accessed on 21 July 2020).

8. Wood, S.A.; Tirfessa, D.; Baudron, F. Soil organic matter underlies crop nutritional quality and productivity in smallholder agriculture. Agric. Ecosyst. Environ. 2018, 266, 100-108. [CrossRef]

9. Worthington, V. Nutritional quality of organic versus conventional fruits, vegetables, and grains. J. Altern. Complement. Med. 2001, 7, 161-173. [CrossRef] [PubMed]

10. Murphy, K.; Hoagland, L.; Reeves, P.; Jones, S. Effect of cultivar and soil characteristics on nutritional value in organic and conventional wheat. In Proceedings of the 16th IFOAM Organic World Congress 4, Modena, Italy, 16-20 June 2008.

11. Lal, R. Soil erosion and the global carbon budget. Environ. Int. 2003, 29, 437-450. [CrossRef]

12. Horn, R.; Lal, R. Soils in Agricultural Engineering: Effect of Land-use Management Systems on Mechanical Soil Processes. In Hydrogeology, Chemical Weathering, and Soil Formation; Hunt, A., Ed.; Wiley \& Sons: Hoboken, NJ, USA, 2020.

13. Lal, R. Soil health and carbon management. Food Energy Secur. 2016, 5, 212-222. [CrossRef]

14. Lal, R. Soil degradation as a reason for inadequate human nutrition. Food Secur. 2009, 1, 45-57. [CrossRef]

15. Lal, R. Degradation and resilience of soils. Philos. Trans. R. Soc. B Biol. Sci. 1997, 352, 997-1010. [CrossRef]

16. Blum, W.E.H. Basic concepts: Degradation, resilience, and rehabilitation. In Methods for Assessment of Soil Degradation. Advances in Soil Science; Lal, R., Blum, W.H., Valentine, C., Stewart, B.A., Eds.; CRC Press: Boca Raton, FL, USA, 1998; pp. 1-16.

17. Seybold, C.A.; Herrick, J.E.; Brejda, J.J. Soil resilience: A fundamental component of soil quality. Soil Sci. 1999, 164, 224-234. [CrossRef]

18. Griffiths, B.S.; Philippot, L. Insights into the resistance and resilience of the soil microbial community. FEMS Microbiol. Rev. 2013, 37, 112-129. [CrossRef]

19. FAO \& ITPS. Status of the World's Soil Resources (SWSR)-Main Report. Food and Agriculture Organization of the United Nations and Intergovernmental Technical Panel on Soils; FAO: Rome, Italy, 2015.

20. Vogel, H.-J.; Eberhardt, E.; Franko, U.; Lang, B.; Ließ, M.; Weller, U.; Wiesmeier, M.; Wollschläger, U. Quantitative Evaluation of Soil Functions: Potential and State. Front. Environ. Sci. 2019, 7, 164. [CrossRef]

21. Moran, D.; Cossar, F.; Merkle, M.; Alexander, P. UK food system resilience tested by COVID-19. Nat. Food 2020, 1, 242. [CrossRef] [PubMed]

22. Barrett, C.B. Actions now can curb food systems fallout from COVID-19. Nat. Food 2020. [CrossRef]

23. Lal, R.; Horn, R.; Kosaki, T. Soil and the Sustainable Development Goals; Catena-Scheizerbart: Stuttgart, Germany, 2018.

24. Rigden, A.J.; Mueller, N.D.; Holbrook, N.M.; Pillai, N.; Huybers, P. Combined influence of soil moisture and atmospheric evaporative demand is important for accurately predicting US maize yields. Nat. Food 2020, 1, 127-133. [CrossRef]

25. Cania, B.; Vestergaard, G.; Suhadolc, M.; Mihelič, R.; Krauss, M.; Fliessbach, A.; Mäder, P.; Szumełda, A.; Schloter, M.; Schulz, S. Site-Specific Conditions Change the Response of Bacterial Producers of Soil Structure-Stabilizing Agents Such as Exopolysaccharides and Lipopolysaccharides to Tillage Intensity. Front. Microbiol. 2020, 11, 568. [CrossRef]

26. Martin, G.; Barth, K.; Benoit, M.; Brock, C.; Destruel, M.; Dumont, B.; Grillot, M.; Hübner, S.; Magne, M.A.; Moerman, M.; et al. Potential of multi-species livestock farming to improve the sustainability of livestock farms: A review. Agric. Syst. 2020, 181, 102821. [CrossRef]

27. Lal, R. Integrating Livestock with Crops and Trees. Front. Food Syst. 2020, in press. 
28. De Crevecoeur, J. Letters from an American Farmer (Reprinted from the Original Edition); Fox and Duffield: New York, NY, USA, 1904.

29. Albrecht, A. Soil Fertility and Animal Health; Fred Hahne Printing Company: Oklahoma City, OK, USA, 1958.

30. Brevik, E.C.; Steffan, J.J.; Rodrigo-Comino, J.; Neubert, D.; Burgess, L.C.; Cerdà, A. Connecting the public with soil to improve human health. Eur. J. Soil Sci. 2019, 70, 898-910. [CrossRef]

31. Jones, S.D. Death in a Small Package: A Short History of Anthrax; The Johns Hopkins University Press: Baltimore, MD, USA, 2010. [CrossRef]

32. Brevik, E.C.; Sauer, T.J. The past, present, and future of soils and human health studies. Soil 2015, 1, 35-46. [CrossRef]

33. Loynachan, T. Human Disease from Introduced and Resident Soilborne Pathogens. In Soils and Human Health; Brevik, E.C., Burgess, L.C., Eds.; CRC Press: Boca Raton, FL, USA, 2013; pp. 107-136. [CrossRef]

34. Jeffery, S.; van der Putten, W.H. Soil Borne Diseases of Humans; Publications Office of the European Union: Luxembourg, 2011. [CrossRef]

35. Oliver, M.A. Soil and human health: A review. Eur. J. Soil Sci. 1997, 48, 573-592. [CrossRef]

36. Hurst, C.J.; Gerba, C.P.; Cech, I. Effects of environmental variables and soil characteristics on virus survival in soil. Appl. Environ. Microbiol. 1980, 40, 1067-1079. [CrossRef] [PubMed]

37. Abrahams, P.W. Soils: Their implications to human health. Sci. Total Environ. 2002, 291, 1-32. [CrossRef]

38. David Walter, W.; Walsh, D.P.; Farnsworth, M.L.; Winkelman, D.L.; Miller, M.W. Soil clay content underlies prion infection odds. Nat. Commun. 2011, 2, 200. [CrossRef] [PubMed]

39. Qu, G.; Li, X.; Hu, L.; Jiang, G. An Imperative Need for Research on the Role of Environmental Factors in Transmission of Novel Coronavirus (COVID-19). Environ. Sci. Technol. 2020, 54, 3730-3732. [CrossRef]

40. Smith, P.; Gregory, P.J.; Van Vuuren, D.; Obersteiner, M.; Havlík, P.; Rounsevell, M.; Woods, J.; Stehfest, E.; Bellarby, J. Competition for land. Philos. Trans. R. Soc. Lond. Ser. B Biol. Sci. 2010, 365, 2941-2957. [CrossRef]

41. Bren d'Amour, C.; Reitsma, F.; Baiocchi, G.; Barthel, S.; Güneralp, B.; Erb, K.-H.; Haberl, H.; Creutzig, F.; Seto, K.C. Future urban land expansion and implications for global croplands. Proc. Natl. Acad. Sci. USA 2017, 114, 8939-8944. [CrossRef]

42. Olfs, H.W.; Blankenau, K.; Brentrup, F.; Jasper, J.; Link, A.; Lammel, J. Soil- and plant-based nitrogen-fertilizer recommendations in arable farming. J. Plant Nutr. Soil Sci. 2005, 168, 414-431. [CrossRef]

43. Gilbert, N. The disappearing nutrient. Nature 2009, 461, 716-718. [CrossRef]

44. Frossard, E.; Bünemann, E.; Jansa, J.; Oberson, A.; Feller, C. Concepts and practices of nutrient management in agro-ecosystems: Can we draw lessons from history to design future sus, tainable agricultural production systems? Bodenkultur 2009, 60, 43-60.

45. Martínez-Alcántara, B.; Martínez-Cuenca, M.-R.; Bermejo, A.; Legaz, F.; Quiñones, A. Liquid Organic Fertilizers for Sustainable Agriculture: Nutrient Uptake of Organic versus Mineral Fertilizers in Citrus Trees. PLOS ONE 2016, 11, e0161619.

46. Ye, L.; Zhao, X.; Bao, E.; Li, J.; Zou, Z.; Cao, K. Bio-organic fertilizer with reduced rates of chemical fertilization improves soil fertility and enhances tomato yield and quality. Sci. Rep. 2020, 10, 177. [CrossRef] [PubMed]

47. Nacke, H.; Gonçalves, A.C.J.; Schwantes, D.; Nava, I.A.; Strey, L.; Coelho, G.F. Availability of heavy metals $(\mathrm{Cd}, \mathrm{Pb}, \mathrm{And} \mathrm{Cr})$ in agriculture from commercial fertilizers. Arch. Environ. Contam. Toxicol. 2013, 64, 537-544. [CrossRef] [PubMed]

48. Enti-Brown, S.; Yeboah, P.O.; Akoto-Bamford, S.; Anim, A.K.; Abole, H.; Kpattah, L.; Hanson, J.E.K.; Ahiamadjie, H.; Gyamfi, E.T. Quality control analysis of imported fertilizers used in Ghana: The macronutrients perspective. Proc. Int. Acad. Ecol. Environ. Sci. 2012, 2, 27-40.

49. Gong, Q.; Chen, P.; Shi, R.; Gao, Y.; Zheng, S.-A.; Xu, Y.; Shao, C.; Zheng, X. Health Assessment of Trace Metal Concentrations in Organic Fertilizer in Northern China. Int. J. Environ. Res. Public Health 2019, 16, 1031. [CrossRef] [PubMed]

50. Withers, P.J.A.; Ulén, B.; Stamm, C.; Bechmann, M. Incidental phosphorus losses-Are they significant and can they be predicted? J. Plant Nutr. Soil Sci. 2003, 166, 459-468. [CrossRef]

51. Schoumans, O.F.; Chardon, W.J. Risk assessment methodologies for predicting phosphorus losses. J. Plant Nutr. Soil Sci. 2003, 166, 403-408. [CrossRef] 
52. Butterbach-Bahl, K.; Gundersen, P.; Ambus, P.; Augustin, J.; Beier, C.; Boeckx, P.; Dannenmann, M.; Sanchez Gimeno, B.; Kiese, R.; Kitzler, B.; et al. Nitrogen processes in terrestrial ecosystems. In The European Nitrogen Assessment: Sources, Effects and Policy Perspectives; Sutton, M.A., Howard, C.M., Willem Erisman, J., Billen, G., Bleeker, A., Eds.; Cambridge University Press: Cambridge, MA, USA, 2011; pp. 99-125.

53. Haas, C.; Holthusen, D.; Mordhorst, A.; Lipiec, J.; Horn, R. Elastic and plastic soil deformation and its influence on emission of greenhouse gases. Int. Agrophysics 2016, 30, 173-184. [CrossRef]

54. Singh, B.R.; Tindwa, H.; Kashem, A.M.; Panghaal, D.; Semu, E. Heavy Metals Bioavailability in Soils and Impact on Human Health. In Soil and Human Health; Lal, R., Ed.; CRC Press: Boca Raton, FL, USA, 2020.

55. Springmann, M.; Clark, M.; Mason-D'Croz, D.; Wiebe, K.; Bodirsky, B.L.; Lassaletta, L.; de Vries, W.; Vermeulen, S.J.; Herrero, M.; Carlson, K.M.; et al. Options for keeping the food system within environmental limits. Nature 2018, 562, 519-525. [CrossRef]

56. Mahurpawar, M. Effects of heavy metals on human health. Int. J. Res.-Granthaalayah 2015, 2350, $2394-3629$.

57. Breure, A.M.; Lijzen, J.P.A.; Maring, L. Soil and land management in a circular economy. Sci. Total Environ. 2018, 624, 1125-1130. [CrossRef]

58. Geissdoerfer, M.; Savaget, P.; Bocken, N.M.P.; Hultink, E.J. The Circular Economy-A new sustainability paradigm? J. Clean. Prod. 2017, 143, 757-768. [CrossRef]

59. Andersen, M.S. An introductory note on the environmental economics of the circular economy. Sustain. Sci. 2007, 2, 133-140. [CrossRef]

60. Arnfield, A.J. Two decades of urban climate research: A review of turbulence, exchanges of energy and water, and the urban heat island. Int. J. Climatol. 2003, 23, 1-26. [CrossRef]

61. Schram-Bijkerk, D.; Otte, P.; Dirven, L.; Breure, A.M. Indicators to support healthy urban gardening in urban management. Sci. Total Environ. 2018, 621, 863-871. [CrossRef]

62. Glaser, B.; Birk, J.J. State of the scientific knowledge on properties and genesis of Anthropogenic Dark Earths in Central Amazonia (terra preta de índio). Geochim. Cosmochim. Acta 2012, 82, 39-51. [CrossRef]

63. Andrews, J.E.; Brimblecombe, P.; Jickells, T.D.; Liss, P.S.; Reid, B. An Introduction to Environmental Chemistry; Blackwell Publishing Ltd.: Hoboken, NJ, USA, 2004.

64. Mukumbuta, I.; Hatano, R. Do tillage and conversion of grassland to cropland always deplete soil organic carbon? Soil Sci. Plant Nutr. 2020, 66, 76-83. [CrossRef]

65. Jin, T.; Shimizu, M.; Marutani, S.; Desyatkin, A.R.; Iizuka, N.; Hata, H.; Hatano, R. Effect of chemical fertilizer and manure application on $\mathrm{N} 2 \mathrm{O}$ emission from reed canary grassland in Hokkaido, Japan. Soil Sci. Plant Nutr. 2010, 56, 53-65. [CrossRef]

66. Yamane, T.; Komada, M.; Koga, N.; Nishimura, S.; Kato, N. Effects of urea and lime nitrogen in pelleted cattle manure compost on nitrous oxide emissions from soils. Jpn. J. Soil Sci. Plant Nutr. 2017, 88, 413-419.

67. Cordell, D.; White, S. Life's Bottleneck: Sustaining the World's Phosphorus for a Food Secure Future. Annu. Rev. Environ. Resour. 2014, 39, 161-188. [CrossRef]

68. Bouma, J.; McBratney, A. Framing soils as an actor when dealing with wicked environmental problems. Geoderma 2013, 201, 130-139. [CrossRef]

69. Lal, R. Managing world soils for food security and environmental quality. Adv. Agron. 2001, 74, 155-192.

70. Lal, R. Sustainable Development Goals and the Intenational Union of Soil Sciences. In Soil and Sustainable Development Goals; Lal, R., Horn, R., Kosaki, T., Eds.; Catena-Scheizerbart: Stuttgart, Germany, 2018; pp. 189-196.

71. Bauwens, M.; Compernolle, S.; Stavrakou, T.; Müller, J.-F.; van Gent, J.; Eskes, H.; Levelt, P.F.; van der A, R.; Veefkind, J.P.; Vlietinck, J.; et al. Impact of coronavirus outbreak on NO2 pollution assessed using TROPOMI and OMI observations. Geophys. Res. Lett. 2020, e2020GL087978. [CrossRef]

72. Shi, X.; Brasseur, G.P. The Response in Air Quality to the Reduction of Chinese Economic Activities during the COVID-19 Outbreak. Geophys. Res. Lett. 2020, e2020GL088070.

73. Ogen, Y. Assessing nitrogen dioxide $\left(\mathrm{NO}_{2}\right)$ levels as a contributing factor to coronavirus (COVID-19) fatality. Sci. Total Environ. 2020, 726, 138605. [CrossRef] [PubMed]

74. Lal, R. Soil Science Beyond COVID-19. J. Soil Water Conserv. 2020, 75, 1-3. [CrossRef]

75. Bekchanov, M.; Mirzabaev, A. Circular economy of composting in Sri Lanka: Opportunities and challenges for reducing waste related pollution and improving soil health. J. Clean. Prod. 2018, 202, 1107-1119. [CrossRef]

76. Bloomfield, L.S.P.; McIntosh, T.L.; Lambin, E.F. Habitat fragmentation, livelihood behaviors, and contact between people and nonhuman primates in Africa. Landsc. Ecol. 2020, 35, 985-1000. [CrossRef] 
77. Yang, C.; Raskin, R.; Goodchild, M.; Gahegan, M. Geospatial Cyberinfrastructure: Past, present and future. Comput. Environ. Urban Syst. 2010, 34, 264-277. [CrossRef]

78. Terribile, F.; Agrillo, A.; Bonfante, A.; Buscemi, G.; Colandrea, M.; D’Antonio, A.; De Mascellis, R.; De Michele, C.; Langella, G.; Manna, P.; et al. A Web-based spatial decision supporting system for land management and soil conservation. Solid Earth 2015, 6, 903-928. [CrossRef]

79. Terribile, F.; Bonfante, A.; D'Antonio, A.; De Mascellis, R.; De Michele, C.; Langella, G.; Manna, P.; Mileti, F.A.; Vingiani, S.; Basile, A. A geospatial decision support system for supporting quality viticulture at the landscape scale. Comput. Electron. Agric. 2017, 140, 88-102. [CrossRef]

80. Manna, P.; Bonfante, A.; Colandrea, M.; Di Vaio, C.; Langella, G.; Marotta, L.; Mileti, F.A.; Minieri, L.; Terribile, F.; Vingiani, S.; et al. A geospatial decision support system to assist olive growing at the landscape scale. Comput. Electron. Agric. 2020, 168, 105143. [CrossRef]

81. Marano, G.; Langella, G.; Basile, A.; Cona, F.; De Michele, C.; Manna, P.; Teobaldelli, M.; Saracino, A.; Terribile, F. A Geospatial Decision Support System Tool for Supporting Integrated Forest Knowledge at the Landscape Scale. Forests 2019, 10, 690. [CrossRef]

82. Piero, M.; Angelo, B.; Antonello, B.; Amedeo, D.; Carlo, D.M.; Michela, I.; Giuliano, L.; Florindo, M.A.; Paolo, P.; Simona, V.; et al. Soil Sealing: Quantifying Impacts on Soil Functions by a Geospatial Decision Support System. Land Degrad. Dev. 2017, 28, 2513-2526. [CrossRef]

83. Langella, G.; Basile, A.; Giannecchini, S.; Moccia, F.D.; Mileti, F.A.; Munafó, M.; Pinto, F.; Terribile, F. SoilMonitor: An internet platformto challenge soil sealing in 3 Italy. Land Degrad. Dev. 2020, in press. [CrossRef]

84. Siche, R. What is the impact of COVID-19 disease on agriculture? Sci. Agropecu. 2020, 11, 3-9. [CrossRef]

85. Atkeson, A. What Will Be the Economic Impact of COVID-19 in the US? Rough Estimates of Disease Scenarios (No. w26867); National Bureau of Economic Research: Cambridge, MA, USA, 2020.

86. Sumner, A.; Hoy, C.; Ortiz-Juarez, E. Estimates of the Impact of COVID-19 on Global Poverty; UNU-Wider: Helsinki, Finland, 2020; pp. 800-809. [CrossRef]

87. Hsiang, S.; Allen, D.; Annan-Phan, S.; Bell, K.; Bolliger, I.; Chong, T.; Druckenmiller, H.; Hultgren, A.; Huang, L.Y.; Krasovich, E.; et al. The Effect of Large-Scale Anti-Contagion Policies on the Coronavirus (COVID-19) Pandemic. medRxiv 2020. [CrossRef]

88. Van Lancker, W.; Parolin, Z. COVID-19, school closures, and child poverty: A social crisis in the making. Lancet Public Health 2020, 5, e243-e244. [CrossRef]

89. Dunn, C.G.; Kenney, E.; Fleischhacker, S.E.; Bleich, S.N. Feeding Low-Income Children during the Covid-19 Pandemic. N. Engl. J. Med. 2020, 382, e40. [CrossRef]

90. Rundle, A.G.; Park, Y.; Herbstman, J.B.; Kinsey, E.W.; Wang, Y.C. COVID-19-Related School Closings and Risk of Weight Gain Among Children. Obesity 2020, 28, 1008-1009. [CrossRef]

91. Sajadi, M.M.; Habibzadeh, P.; Vintzileos, A.; Shokouhi, S.; Miralles-Wilhelm, F.; Amoroso, A. Temperature and Latitude Analysis to Predict Potential Spread and Seasonality for COVID-19. SSRN Electron. J. 2020. [CrossRef]

92. Dawson, L.A.; Hillier, S. Measurement of soil characteristics for forensic applications. Surf. Interface Anal. 2010, 42, 363-377. [CrossRef]

93. Squazzoni, F.; Polhill, J.G.; Edmonds, B.; Ahrweiler, P.; Antosz, P.; Scholz, G.; Chappin, E.; Borit, M.; Verhagen, H.; Giardini, F.; et al. Computational Models That Matter During a Global Pandemic Outbreak: A Call to Action. J. Artif. Soc. Soc. Simul. 2020, 23, 10. [CrossRef]

94. Pasternak, Z.; Luchibia, A.O.; Matan, O.; Dawson, L.; Gafny, R.; Shpitzen, M.; Avraham, S.; Jurkevitch, E. Mitigating temporal mismatches in forensic soil microbial profiles. Aust. J. Forensic Sci. 2019, 51, 685-694. [CrossRef]

95. Dawson, L.A.; Macdonald, L.M.; Ritz, K. Plant wax compounds and soil microbial DNA profiles to ascertain urban land use type. Geol. Soc. Lond. Spec. Publ. 2019, 492, SP492-2018-65. [CrossRef]

96. Dawson, L.A.; Auchie, D.; Parratt, D. The judicial system, reporting and giving evidence in court. In A Guide to Forensic Geology; Donnelly, L., Pirrie, D., Harrison, M., Ruffell, A., Dawson, L., Eds.; Geological Society: London, UK, 2020.

97. Saadat, S.; Rawtani, D.; Hussain, C.M. Environmental perspective of COVID-19. Sci. Total Environ. 2020, 728, 138870. [CrossRef] 
98. Zambrano-Monserrate, M.A.; Ruano, M.A.; Sanchez-Alcalde, L. Indirect effects of COVID-19 on the environment. Sci. Total Environ. 2020, 728, 138813. [CrossRef] [PubMed]

99. Lal, R. Promoting "4 Per Thousand" and "Adapting African Agriculture" by south-south cooperation: Conservation agriculture and sustainable intensification. Soil Tillage Res. 2019, 188, 27-34. [CrossRef]

100. Nicola, M.; Alsafi, Z.; Sohrabi, C.; Kerwan, A.; Al-Jabir, A.; Iosifidis, C.; Agha, M.; Agha, R. The Socio-Economic Implications of the Coronavirus and COVID-19 Pandemic: A Review. Int. J. Surg. 2020, 78, 185-193. [CrossRef]

(C) 2020 by the authors. Licensee MDPI, Basel, Switzerland. This article is an open access article distributed under the terms and conditions of the Creative Commons Attribution (CC BY) license (http://creativecommons.org/licenses/by/4.0/). 